\title{
PENGARUH MODEL PEMBELAJARAN ICARE BERBANTUAN MULTIMEDIA INTERAKTIF TERHADAP PRESTASI BELAJAR MATEMATIKA SISWA KELAS VIII SMPN 1 BANGLI
}

\author{
I. A. G. S. Wahyuni, I. N. Sukajaya, N. M. Juniantari \\ Jurusan Matematika Universitas Pendidikan Ganesha \\ Singaraja, Indonesia \\ e-mail: gede.sri.wahyuni, nyoman.sukajaya,mdjuniantari\}@undiksha.ac.id
}

\begin{abstract}
Abstrak
Penelitian ini bertujuan untuk mengetahui pengaruh model pembelajaran ICARE berbantuan multimedia interaktif terhadap prestasi belajar matematika siswa, serta memberikan alternatif dalam memilih model pembelajaran yang dapat meningkatkan prestasi belajar matematika siswa. Jenis penelitian ini adalah eksperimen semu dengan desain penelitian adalah Post Test Only Control Group. Populasi penelitian ini adalah seluruh siswa kelas VIII SMPN 1 Bangli tahun ajaran 2018/2019. Sampel dalam penelitian ini adalah siswa kelas VIII C dan VIII D yang diambil dengan menggunakan teknik cluster random sampling. Data prestasi belajar matematika siswa diukur menggunakan tes prestasi belajar matematika berbentuk uraian yang diberikan di akhir penelitian. Data hasil tes kemampuan pemecahan masalah matematika dianalisis menggunakan uji-t satu ekor dengan taraf siginifikansi 5\%. Hasil penelitian menunjukkan bahwa $t_{\text {hitung }}=2,1086>t_{\text {tabel }}=0,0630$ sehingga $H_{0}$ ditolak. Ini berarti bahwa prestasi belajar siswa yang dibelajarkan dengan menggunakan menggunakan ICARE berbantuan multimedia interaktif lebih baik daripada prestasi belajar siswa yang dibelajarkan dengan pembelajaran konvensional. Dengan demikian dapat disimpulkan bahwa terdapat pengaruh model pembelajaran ICARE berbantuan multimedia interaktif terhadap prestasi belajar matematika siswa.

Kata kunci: model pembelajaran ICARE, multimedia interaktif, prestasi belajar matematika.
\end{abstract}

\begin{abstract}
This study aims at investigating the effect of ICARE-assisted interactive multimedia learning models on students 'mathematics learning achievements, and providing an alternative in choosing learning models that can improve students' mathematics learning achievement. The design of this study used post test only control group design of quasi experimental research. The population of this study was all eighth grade students at SMPN 1 Bangli in academic year 2018/2019. VIII C and VIII D classes were selected to be the sample of the study by using cluster random sampling technique. Mathematics learning achievement test in the form of description was used to collect the data on students mathematics learning achievements. Data from the test of mathematical problem solving ability were analyzed by using one-tailed t-test with a significance level of $5 \%$. The results showed that $t_{\text {hitung }}=2,1086>t_{\text {tabel }}=0,0630$ they so rejected. This means that students' learning achievements taught by using ICARE assisted of interactive multimedia was better than students' learning achievement taught by conventional learning. It indicated that there is an effect of ICARE- assisted interactive multimedia learning model toward students' mathematics learning achievement.
\end{abstract}

Keywords: ICARE learning model, interactive multimedia, mathematics learning achievement.

\section{PENDAHULUAN}

Aspek penting dalam proses pembelajaran adalah aspek afektif, kognitif, dan psikomotor. Diantara ketiga aspek tersebut aspek kognitiflah yang paling terlihat jelas hasilnya dalam proses pembelajaran. Aspek kognitif pada umumnya dapat dilihat dalam 
bentuk prestasi belajar. Prestasi belajar sering diartikan sebagai hasil yang telah dicapai seperti yang disampaikan oleh Haryati (2008: 43) "prestasi merupakan hasil usaha yang dilakukan dan menghasilkan perubahan yang dinyatakan dalam bentuk simbol untuk menunjukkan kemampuan pencapaian dalam hasil kerja dalam waktu tertentu". Prestasi belajar dianggap sebagai hasil yang diperoleh setelah melaksanakan kegiatan pembelajaran. Hal tersebut juga diperkuat dengan pendapat Winkel (1996:162) mengatakan bahwa "prestasi belajar adalah suatu bukti keberhasilan belajar atau kemampuan seseorang siswa dalam melakukan kegiatan belajarnya sesuai dengan bobot yang dicapainya".

Dari beberapa penjelasan mengenai prestasi belajar, maka dapat disimpulkan bahwa prestasi belajar merupakan tolak ukur keberhasilan suatu proses pembelajaran. Dengan kata lain prestasi belajar yang diperoleh peserta didik mencerminkan tingkat penguasaan terhadap materi yang diajarkan. Prestasi belajar siswa dapat diketahui setelah mengadakan evaluasi. Dari hasil evaluasi tersebut dapat ditunjukkan sejauh mana siswa telah memahami materi yang diberikan dalam proses pembelajaran.

Pada saat ini kondisi prestasi belajar siswa khususnya pada mata pelajaran matematika masih tergolong rendah. Rendahnya prestasi belajar matematika siswa tersebut dapat ditunjukan dari hasil Ujian Nasional (UN) yang semakin menurun. Rendahnya prestasi belajar dapat dipengaruhi oleh beberapa faktor, baik yang berasal dari diri individu maupun yang berasal dari luar individu. Penelitian Ilham Ansori (2013), menunjukkan bahwa faktor yang menyebabkan rendahnya prestasi belajar siswa adalah inteligensi, minat, bakat, kematangan, dan kesiapan belajar yang kemudian disebut dengan gaktor internal. Selain faktor internal, terdapat pula faktor lain yang menjadi penyebab rendahnya prestasi belajar yaitu faktor eksternal yang berasal dari lingkungan keluarga, lingkungan sekolah dan lingkungan masyarakat. Hasil penelitian tersebut diperkuat oleh Slameto (2003) yang menyatakan tinggi rendahnya prestasi belajar siswa dipengaruhi oleh dua faktor yaitu faktor internal dan eksternal. Faktor internal yaitu faktor yang berasal dari dalam diri siswa yang meliputi faktor jasmaniah dan psikologi. Faktor jasmaniah menyangkut alat indra yang berfungsi, sedangkan psikologi menyangkut dengan kecerdasan yang dimiliki siswa. Faktor eksternal yaitu faktor yang berada di luar diri siswa, yaitu faktor keluarga, sekolah serta masyarakat. Faktor keluarga, menyangkut bagaimana orang tua siswa tersebut mendidik anaknya, bagaimana hubungan siswa dengan orangtuanya, dan latar belakang keluarganya. Faktor sekolah meliputi kurikulum, hubungan guru dengan siswa serta metode pembelajaran yang diterapkan di kelas. Faktor masyarakat meliputi kegiatan siswa dalam bermasyarakat serta ergaul di lingkungannya.

Faktor yang dapat mempengaruh prestasi belajar yang dapat terlihat secara umum dan diberikan solusi adalah faktor eksternal. Seperti yang disampaikan Muhibbin Syah (2011: 145) faktor pendekatan belajar juga mempengaruhi prestasi belajar, yang meliputi strategi, metode, serta model pembelajaran yang digunakan dalam proses pembelajaran. Pemilihan model pembelajaran yang tepat dapat mempengaruhi peningkatan prestasi belajar siswa. Salah satu model pembelajaran yang tepat diterapkan saat ini adalah ICARE, yang mana dalam model pembelajaran ICARE tersebut siswa diberikan kesempatan untuk mendapatkan pengalaman langsung dari pembelajaran dengan mengaplikasikan apa yang mereka dapat pada setiap sesi pembelajaran.

Model pembelajaran ICARE memiliki langkah-langkah Introduction, connection, application, reflection, dan extension. Pada tahap Introduction (Pendahuluan), guru akan menanamkan pemahaman tentang isi 
dari pelajaran kepada siswa. Guru akan menjelaskan tujuan pelajaran dan apa yang akan dicapai atau hasil yang akan diperoleh selama pembelajaran. Pada tahapan ini, guru akan menjelaskan secara sederhana dan singkat.

Pada tahapan Connection (Penghubung), guru meminta siswa untuk mengingat dan menyampaikan kembali materi apa yang telah dipelajari pada pertemuan sebelumnya. Kegiatan lain yang dapat dilakukan guru, yaitu dengan mengembangkan sebuah kegiatan yang dapat dilakukan siswa sendiri. Setelah itu, guru bisa menghubungkan peserta didik dengan informasi baru. Hal ini dapat dilakukan melalui presentasi atau penjelasan yang sederhana.

Tahap ketiga yaitu tahap Application (Penerapan). Pada tahap application adalah tahap yang paling penting dari proses pelajaran. Setelah peserta didik memperoleh informasi atau kecakapan baru melalui tahap connection, siswa akan diberikan kesempatan untuk menerapkan pengetahuan serta kecakapan tersebut. Oleh karena itu, tahapan ini akan berlangsung paling lama dalam proses pembelajarn. Pada tahapan ini, guru dapat membagi siswa kedalam kelompok yang beranggotakan 4 sampai 5 orang, kemudian siswa akan mendiskusikan terkait penerapan dari pelajaran yang diberikan oleh guru.

Bagian refleksi merupakan ringkasan dari proses pembelajaran yang dilakukan. Peserta didik akan diberikan kesempatan untuk merefleksikan apa yang telah mereka pelajari. Guru akan bertugas menilai sejauh mana keberhasilan pembelajaran. Kegiatan pada tahap ini dapat dilakukan dengan melibatkan diskusi kelompok, salah satu perwakilan kelompok akan ditunjuk untuk menjelaskan kembali terkait pelajaran yang telah dipelajari. Peserta didik juga dapat melakukan kegiatan penulisan mandiri, melalui kegiatan meringkas isi materi atau melalui kegiatan tes lisan.Tahap ini menyediakan kesempatan bagi para peserta untuk mengungkapkan apa yang telah mereka pelajari.

Pada tahap Extension ini, guru menyediakan kegiatan yang dapat dilakukan siswa setelah pelajaran berakhir untuk memperkuat dan memperluas pembelajaran. Kegiatan ini dapat dengan menyediakan materi yang akan dibahas pada pertemuan selanjutnya ataupun melalui pekerjaan rumah. Kegiatan ini bertujuan untuk menilai sejauh mana siswa dapat secara otomatis menggunakan apa yang telah mereka pelajari.

Untuk kelebihan dan keefektifan dari model pembelajaran ICARE dapat ditunjukan melalui riset yang dilakukan oleh beberapa peneliti. Salah satu hasil riset yang dilakukan oleh Siti Maryam (2016) menunjukkan bahwa penerapan pembelajaran matematika dengan model pembelajaran ICARE dapat meningkatkan kemampuan pemecahan masalah matematis siswa. Siswa dapat menyelesaikan soal yang diberikan pada siklus I dan II dengan baik.

Namun, dalam penerapanya model pembelajaran ICARE juga memiliki kelemahan, yaitu memerlukan waktu yang lama untuk membuat siswa memahami permasalahan yang diberikan. Oleh karena itu perlu adanya sebuah alternatif untuk menutupi kelemahan tersebut. Salah satu alternatif yang dapat mengurangi kelemahan yang terjadi pada model pembelajaran ICARE adalah dengan menerapkan multimedia interaktif. Multimedia interaktif memiliki fungsi memvisualisasikan segala sesuatu yang tidak dapat dilihat atau sulit dibayangkan, sehingga nampak dengan jelas dan dapat menimbulkan pengertian dan mempermudah siswa untuk memahami permasalahan yang diberikan. Menurut Rudy Sumiharsono (2017) salah satu fungsi pokok media pembelajaran berupa multimedia innteraktif dalam pengajaran adalah mempercepat proses belajar mengajar dan membantu siswa dalam menangkap pengertian yang diberikan guru. Dari pemaparan tersebut, terlihat 
jelas bahwa media pembelajaran berupa multimedia interaktif dapat menutupi kelemahan dari penerapan model pembelajaran ICARE. Oleh karena itu, penulis tertarik untuk melakukan sebuah penelitian dengan judul "Pengaruh Model Pembelajaran ICARE Berbantuan Multimedia Interaktif terhadap Prestasi Belajar Matematika Siswa Kelas VIII SMP Negeri 1 Bangli".

\section{METODE}

Penelitian ini merupakan penelitian eksperimen semu (quasi experiment), karena tidak seluruh variabelnya diatur dan dikontrol secara ketat. Rancangan penelitian ini menggunakan post test only control group design, artinya pada pertemuan terakhir kedua kelompok tersebut akan diberikan tes yang sama (post-test), selanjutnya skor dari post-test tersebut akan digunakan sebagai pedoman dalam melakukan uji hipotesis.

Populasi dalam penelitian ini adalah seluruh siswa kelas VIII SMP Negeri 1 Bangli tahun pelajaran 2018/2019 yang terdiri dari 10 kelas. Dari kesepuluh kelas yang dinyatakan sebagai populasi dipilih dua kelas sebagai sampel. Sampel yang digunakan diperoleh melalui teknik cluster random sampling yaitu pemilihan sampel yang dilakukan secara acak tanpa memperhatikan strata yang ada dalam populasi. Setelah terpilih dua kelas tersebut, akan dilakukan uji kesetaraan dengan uji-t untuk mengetahui homogenitas kedua kelas. Data yang digunakan sebagai dasar pengujian kesetaraan pada penelitian ini adalah nilai ulangan umum dua kelas yang terpilih.

Jika kedua kelas dinyatakan tidak setara maka akan dilakukan pengundian ulang sehingga diperoleh dua kelas yang setara yaitu kelas VIII C dan VIII D. Dua kelas yang terpilih, diundi kembali untuk menentukan kelompok kontrol dan kelompok eksperimen. Berdasarkan hasil pengundian, terpilih kelas VIII C sebagai kelompok eksperimen dan kelas VIII D sebagai kelompok kontrol.

Terdapat dua jenis variabel yang terlibat dalam penelitian ini, yaitu variabel bebas (independent variable) dan variabel terikat (dependent variable). Variabel bebas dalam penelitian ini adalah model pembelajaran, dimana model pembelajaran ICARE berbantuan multimedia interaktif diterapkan pada kelas eksperimen dan model pembelajaran konvensional di kelas kontrol. Variabel terikat dalam penelitian ini adalah prestasi belajar maematika siswa kelas VIII SMP Negeri 1 Bangli. Rancangan penelitian ini dapat dilihat pada Tabel 1. Instrumen yang digunakan dalam penelitian ini berupa tes prestasi belajar matematika yang berbentuk uraian. Instrumen yang baik harus memenuhi dua persyaratan penting yaitu valid dan reliabel.

Uji coba instrumen penelitian dilakukan untuk mendapatkan gambaran secara empirik apakah instrumen penelitian berupa tes prestasi belajar matematika siswa layak digunakan sebagai instrumen. Sebelum diberikan kepada siswa yang menjadi sampel penelitian, akan dilakukan beberapa uji terhadap instrumen penelitian untuk mendapatkan tes yang baik. Pertama akan dilakukan uji pakar/ahli untuk mengetahui validitas isi instrumen. Validitas isi dilakukan oleh dua orang pakar yang merupakan dosen di Jurusan Matematika Undiksha.

Perhitungan validitas isi dilakukan dengan formula Gregory dan dari hasil perhitungan diperoleh koefisien validitas isi tes prestasi belajar matematika siswa yang akan diujicobakan adalah 1,00 yang berarti tes prestasi belajar matematika yang akan diuji coba sangat relevan. Selanjutnya, tes prestasi belajar matematika diuji coba pada kelas IX A SMP Negeri 1 Bangli dengan total yang diujicobakan adalah 10 butir soal dan hasilnya digunakan untuk menghitung validitas dan reliabilitas instrumen tersebut.

Salah satu cara untuk mencari koefisien validitas alat evaluasi yang berbentuk uraian adalah dengan menggunakan koefisien korelasi productmoment dari Carl Pearson (Candiasa, 2010a:38). Berdasarkan hasil analisis validitas tes uji coba diperoleh 9 butir soal valid. Selanjutnya, butir soal yang valid diuji reliabilitasnya. Untuk menentukan reliabilitas instrumen bentuk uraian (essay) dapat menggunakan rumus Alpha Cronbach (Erman Suherman, 1993). 
Tabel 1. Rancangan Penelitian

\begin{tabular}{lcc}
\hline Kelompok & Perlakuan & Post test \\
\hline Eksperimen & $X_{1}$ & $Y$ \\
Kontrol & - & $Y$ \\
\hline & (Suharsimi Arikunto, 2006)
\end{tabular}

Keterangan:

$X_{1}=$ Perlakuan berupa penerapan model

pembelajaran ICARE berbantuan multimedia interaktif

$Y=$ post-test

Berdasarkan hasil analisis reliabilitas tes, diperoleh koefisien reliabilitasnya adalah 0,6155 . Hasil tersebut menunjukkan bahwa tes uji coba prestasi belajar matematika siswa reliabel dengan reliabilitas tinggi (baik), sehingga soal-soal tersebut layak untuk digunakan.Dari Sembilan butir soal yang valid dan reliabel, dipilih lima butir soal yang digunakan sebagai tes prestasi belajar matematika siswa, sebab kelima soal tersebut sudah mencakup keseluruhan materi yang diajarkan.

Data prestasi belajar matematika yang telah diperoleh perlu diuji dengan uji prasyarat yaitu uji normalitas dan uji homogenitas. Setelah semua uji prasyarat tersebut terpenuhi selanjutnya dilakukan uji hipotesis untuk memperoleh kesimpulan dari penelitian yang telah dilakukan dengan menggunakan uji-t satu ekor.

\section{HASIL DAN PEMBAHASAN}

Rangkuman analisis terhadap skor prestasi belajar matematika siswa pada kelompok eksperimen dan kelompok kontrol dapat dilihat pada Tabel 2. Pengujian normalitas sebaran data pada penelitian ini dilakukan dengan menggunakkan uji Kolmogorov pada taraf signifikan 5\%. Hasil analisis uji normalitas pada kelompok eksperimen dengan data sebanyak 31 , menunjukkan bahwa nilai $D_{\text {hitung }}$ sebesar 0,117 dan nilai $D_{\text {tabel }}$ sebesar 0,224. Sedangkan, pada kelompok kontrol dengan data sebanyak 31, menunjukkan bahwa $D_{\text {hitung }}$ sebesar 0,132 dan $D_{\text {tabel }}$ sebesar 0,224 . Terlihat
Tabel 2. Rangkuman Analisis terhadap Data Prestasi Belajar Matematika Siswa

\begin{tabular}{cccc}
\hline $\begin{array}{c}\text { Kelas } \\
\text { Sampel }\end{array}$ & $D_{\text {hitung }}$ & $D_{\text {tabel }}$ & Keterangan \\
\hline Eksperimen & 0,117 & 0,224 & Normal \\
Pembanding & 0,132 & 0,224 & Normal \\
\hline
\end{tabular}

bahwa pada kelompok eksperimen dan kelompok kontrol menunjukkan nilai $D_{\text {hitung }}<D_{\text {tabel }}$. Ini berarti, data prestasi belajar matematika siswa berasal dari populasi yang berdistribusi normal. Analisis data dilanjutkan dengan melakukan pengujian homogenitas varians. Pada penelitian ini, pengujian varians dilakukan dengan menggunakkan uji- $F$ dan diperoleh $F_{\text {hitung }}=1,0301$. Berdasarkan tabel untuk taraf signifikan $5 \%, d k$ pembilang $=29$ dan $d k$ penyebut $=30$, diperoleh $F_{\text {tabel }}=1,8347$. Karena $F_{\text {hitung }}<F_{\text {tabel }}$, ini berarti data prestasi belajar matematika siswa mempunyai varians yang homogen.

Hasil uji normalitas dan homogenitas varians pada penelitian ini diperoleh bahwa sebaran data prestasi belajar matematika siswa pada kelompok eksperimen dan kelompok kontrol berdistribusi normal, serta memiliki varians yang homogen. Selanjutnya dilakukan uji hipotesis dengan menggunakkan uji-t satu ekor pada taraf signifikan 5\%. Rangkuman hasil analisis uji-t dapat dilihat pada Tabel 3. Berdasarkan Tabel 3, menunjukkan bahwa $t_{\text {hitung }}>t_{\text {tabel }}$. Ini berarti, prestasi belajar matematika siswa yang dibelajarkan dengan model pembelajaran ICARE berbantuan multimedia interaktif lebih baik daripada prestasi belajar matematika siswa yang dibelajarkan dengan model pembelajaran konvensional.

Terjadinya hal tersebut disebabkan karena adanya perbedaan perlakuan antara kelompok eksperimen dan kelompok kontrol. Perlakuan yang dimaksud adalah perbedaan kegiatan pembelajaran yang berlangsung. Pada kelompok eksperimen, siswa diberikan pembelajaran dengan menerapkan model 
pembelajaran ICARE berbantuan multimedia interaktif yang memiliki kontribusi besar dalam meningkatkan prestasi belajar matematika siswa.

Hal tersebut dapat dilihat dari penerapannya di kelas. Model pembelajaran ICARE berbantuan multimedia interaktif terdiri dari lima tahapan, yaitu introduction (pendahuluan), connection (penghubung), aplication (aplikasi), refflection (refleksi), dan extension (perluasan). Pada tahap introduction (pendahuluan) baik kelas eksperimen maupun kelas kontrol memiliki tahapan yang sama, hanya saja pada kelas eksperimen antusias siswa lebih tinggi karena mereka akan mengikuti pembelajaran dengan model pembelajaran yang berbeda dari biasanya. Sedangkan pada kelas kontrol pada awal pembelajaran guru memberikan salam dan menyampaikan materi kepada siswa sehingga guru masih mendominasi dan siswa hanya menerima informasi dari guru. Hal ini menyebabkan, siswa cenderung tidak mengkonstruksi pengetahuan sendiri dan bergantung pada guru di kelas sehingga belum mampu untuk menemukan konsep sendiri serta belum mampu mengaitkan materi yang akan dibahas dengan materi sebelumnya.

Pada tahapan yang kedua yaitu connection (penghubung), siswa pada kelas eksperimen diajak untuk mengingat kembali materi yang telah mereka peroleh sebelumnya. Materi yang akan diajarkan dikaitkan dengan permasalahan dalam kehidupan sehari-hari yang ada di sekitar siswa. Melalui penayangan video yang ada pada multimedia interaktif guru mengarahkan siswa untuk mengingat

Tabel 3. Rangkuman Hasil Uji- $t$

\begin{tabular}{ccc}
\hline \multirow{2}{*}{ Variabel } & \multicolumn{2}{c}{ Post-test } \\
\cline { 2 - 3 } & $\begin{array}{c}\text { Kelompok } \\
\text { Eksperimen }\end{array}$ & $\begin{array}{c}\text { Kelompok } \\
\text { Kontrol }\end{array}$ \\
\hline$N$ & 31 & 31 \\
$\bar{Y}$ & 81,516 & 74,613 \\
$S D$ & 94,0581 & 6,9025 \\
$S D_{\text {gabungan }}$ & \multicolumn{2}{c}{116,132} \\
$t_{\text {hitung }}$ & \multicolumn{2}{c}{2,1086} \\
$t_{\text {tabel }}$ & \multicolumn{2}{c}{0,0630}
\end{tabular}

materi yang sudah diajarkan sebelumnya yang memiliki kaitan dengan materi baru yang akan diajarkan. Dengan kegiatan tersebut siswa mengetahui bahwa materi sebelumnya memiliki kaitan terhadap materi baru sehingga siswa termotivasi untuk mengingat materi sebelumnya. Pada tahap ini, siswa di kelas eksperimen sangat antusias untuk menghubungkan materi yang dipelajari dengan memberikan contoh dan memberikan pendapat berdasarkan pengalaman mereka dalam kehidupan sehari-hari. Berdasarkan pengamatan peneliti, seringkali siswa mengacungkan tangan dan menyampaikan apa yang mereka lihat terkait dengan konsep yang diajarkan.

Pada tahapan selanjutnya, yaitu tahap aplikasi (application), siswa akan mengaplikasikan konsep yang sudah diperoleh pada tahap hubungan (connection). Siswa menjawab soal latihan yang ada pada LKS atau soal yang diberikan oleh guru. Selama tahap ini berlangsung, siswa dilatih untuk membiasakan keterampilan mereka dalam memahami suatu permasalahan dan memeriksa kembali jawaban yang telah dibuat. Pada kelas eksperimen, siswa antusias dan mampu mengaplikasikan konsep dalam latihan soal yang bervariasi, siswa di kelas eksperimen juga lebih cepat mengaplikasikan materi yang disampaikan karena konsep yang diperoleh sebelumnya pada tahap connection masih mereka ingat, dan multimedia interaktif tersebut siswa dipermudah untuk membayangkan benda abstrak yang berkaitan dengan matei pembelajaran, serta mempermudah siswa memahami maksud yang disampaikan oleh guru. Berbeda dengan siswa pada kelas kontrol, dalam proses diskusi hanya beberapa siswa yang aktif membaca buku mengenai materi yang sedang dibahas dan menjawab soal pada LKS. Beberapa siswa lebih terkesan tidak peduli dengan kelompoknya dan menganggap rekannya lebih mampu dibandingkan dirinya. Hal tersebut membuat siswa kurang aktif untuk mengoptimalkan kemampuan mereka dalam proses belajar mengajar. Beberapa siswa juga mengalami kesulitan dalam 
membayangkan benda abstrak yang dimaksudkan dalam soal.

Kegiatan berdiskusi pada kelas eksperimen lebih aktif dan kondusif dibandingkan kelas kontrol. Pada tahapan refleksi (reflection), salah satu perwakilan kelompok dipilih untuk mempresentasikan hasil diskusinya di depan kelas, sedangkan kelompok lainnya memperhatikan perwakilan kelompok yang presentasi kemudian memberikan tanggapan atau bertanya jika memiliki pendapat yang berbeda. Berdasarkan hasil pengamatan di kelas eksperimen yaitu kelas VIIIC terlihat bahwa siswa lebih berpartisipasi aktif dalam proses pembelajaran, serta setiap anggota kelompok memiliki tanggung jawab yang sama. Setelah kegiatan presentasi kelompok selesai, selanjutnya siswa diminta untuk menyimpulkan pembelajaran yang telah dilaksanakan. Salah satu siswa akan ditunjuk untuk mempresentasikan kesimpulan yang diperoleh. Pada tahap ini peran guru sangat diperlukan untuk memperoleh kesepakatan agar konsep yang ditemukan tidak menyimpang dari tujuan pembelajaran. Setelah diperoleh kesimpulan mengenai materi yang diajarkan, siswa mengerjakan kuis untuk mengukur sejauhmana pemahaman siswa terhadap materi yang diajarkan serta menjadi refleksi terhadap pembelajaran. Tahap selanjutnya yaitu kegiatan lanjutan (extension), siswa pada kelas eksperimen diberikan tugas untuk mengeksplorasi soal yang ada pada multimedia interaktif.

Secara umum berdasarkan pengamatan peneliti pada saat pembelajaran berlangsung menunjukkan bahwa siswa yang mengikuti pembelajaran ICARE berbantuan multimedia interaktif lebih aktif dalam menggali pengetahuannya dengan merangkum dan berdiskusi menjawab soal bersama kelompoknya dibandingkan dengan siswa yang mengikuti pembelajaran konvensional. Melalui bantuan multimedia interaktif dalam proses pembelajaran juga dapat menumbuhkan aktivitas siswa yang lebih antusias sehingga membuat minat siswa dalam belajar meningkat pula. Hal tersebut menjadi salah satu faktor yang membuat rata-rata skor prestasi belajar matematika yang diperoleh di kelas eksperimen lebih tinggi daripada rata-rata skor di kelas kontrol.

\section{SIMPULAN DAN SARAN}

Berdasarkan rumusan masalah, tujuan, hasil analisis, dan pembahasan yang telah diuraikan di depan, dapat disimpulkan bahwa prestasi belajar matematika siswa yang dibelajarkan dengan menggunakan menggunakan ICARE berbantuan multimedia interaktif lebih baik daripada prestasi belajar matematika siswa yang dibelajarkan dengan model pembelajaran konvensional. Oleh karena itu, model pembelajaran ICARE berbantuan multimedia interaktif berpengaruh positif terhadap prestasi belajar matematika siswa kelas VIIIC SMP Negeri 1 Bangli.

Berdasarkan hasil penelitian yang telah dilakukan, peneliti melalui tulisan ini menyampaikan beberapa saran sebagai berikut.

1. Peneliti lain disarankan agar mengujicobakan pengaruh model pembelajaran ICARE berbantuan multimedia interaktif pada aspek lain, misalnya kemampuan berpikir kreatif.

2. Kepada praktisi matematika, khususnya guru mata pelajaran matematika diharapkan untuk menerapkan model pembelajaran ICARE berbantuan multimedia interaktif sebagai salah satu alternatif pembelajaran di kelas mengingat memberikan pengaruf positif terhadap prestasi belajar matematika siswa. Penelitian ini dilakukan pada populasi dan materi pembelajaran yang terbatas. Para peneliti lain yang tertarik disarankan untuk melakukan penelitian terhadap model pembelajaran ICARE dengan populasi yang lebih besar dan materi pembelajaran yang lebih luas untuk mengetahui pengaruh penerapan model pembelajaran ini dalam pembelajaran matematika secara lebih mendalam.

3. Penelitian ini dilakukan untuk melihat pengaruh model pembelajaran terhadap prestasi belajar matematika siswa yang terbatas pada aspek kognitif saja. Para peneliti lain yang 
tertarik disarankan untuk melakukan penelitian terhadap model pembelajaran terhadap prestasi belajar matematika siswa melihat ketiga aspek afektif, kognitif, dan psikomotor.

\section{DAFTAR PUSTAKA}

Ansori, Ilham.2016.Analisis Faktor-Faktor Penyebab Rendahnya Prestasi Belajar Pada Siswa Kelas VIII Sekolah Menengah Pertama.FKIP.Untan Pontianak.

Candiasa. 2010. Statistik Multivariat Disertai Petunjuk Analisis SPSS. Singaraja: Undiksha.

Djamarah, Syaiful Bahri. 1994. Prestasi belajar dan kompetensi guru. Surabaya : Usaha Nasional.

Joyce, Bruce dan Marsha Weil. 1992. Models of Teaching. 4 Ed. USA. Allyn and Bacon.

Kamisa.1997. Kamus Lengkap Bahasa Indonesia, Surabaya: Kartika.

Maryam, Siti.2016. Pembelajaran Matematika dengan Strategi ICARE untuk Meningkatkan Kemampuan Pemecahan Masalah Matematika Siswa. Universitas Islam Negeri Syarif Hidayatullah:Jakarta.

Muhibbin, Syah. 2004. Psikologi Pendidikan. Bandung: Rosda Karya.

Oka, Arya.2017.Media dan Multimedia Pembelajaran.Yogyakarta:

Deepublish.

Oktavianingtyas,Ervin.2013. Studi Tentang Faktor-Faktor Yang Mempengaruhi Prestasi Belajar Mahasiswa Program Studi Pendidikan Matematika FKIP Universitas Jember. Kadikma, 4(2), 13-26.
Riyana, Cepy. 2012. Media Pembelajaran. Jakarta: Direktorat Jendral Pendidikan Islam Kementrian Agung RI.

Slameto. 2003. Belajar dan Faktor-faktor yang Mempengaruhi.Jakarta: Rineka Cipta.

Sucipto, 2010. Penulisan Naskah Pembelajaran Multimedia Interaktif Berbantuan Komputer (Multimedia). Makalah. Yogyakarta: Balai Teknologi Komunikasi Pendidikan (BTJP).

Sudjana, Nana. 1989. Penelitian Hasil Proses Belajar. Bandung: Remaja Rosdakarya.

Sudaryono. 2012. Dasar-dasar Evaluasi Pembelajaran. Graha: Ilmu.

Suharsimi, dkk. 2009. Penelitian Tindakan Kelas. Jakarta: PT Bumi Aksara.

Sumiharsono, Rudy, Hasanah, (2017). Hisbiyatul. Media Pembelajaran. Jember : Pusaka Abadi

Suherman, dkk. 2003. Evaluasi Pembelajaran Matematika. Bandung: UPI.

Suryabrata, Sumadi. 2006. Metodologi Penelitian. Jakarta: PT Raja Grafindo Persada.

Tim penyusun DBE3 USAID.2009.Modul Pelatihan Pengajaran Profesional dan Pembelajaran Bermakna2. Jakarta: DBE3 USAID.

Winkel, W. S. 1996. Psikologi Pendidikan. Jakarta: Grasindo.harya.

Wandah, Wibawanto.2017.Desain dan Pemrograman Multimedia Pembelajaran Interaktif.Jember: Cerdas Ulet Kreatif. 